\title{
Model autonomne kuće kao doprinos održivom razvitku Istre
}

\author{
Bojan Aleksić \\ Osnovna škola Poreč \\ Ul. Karla Huguesa 7, 52440 Poreč \\ bojan1990@yahoo.it
}

\author{
Lidija Runko Luttenberger \\ Sveučilište u Rijeci \\ Sveučilišna avenija 4, 51000 Rijeka \\ lidija.luttenberger@uniri.hr
}

\begin{abstract}
Sažetak
U radu se obrađuju razlozi i koncept gradnje autonomnih kuća u Istri, te način korištenja energije $i$ materijalnih resursa. Pojašnjava se princip samostalne izrade fotonaponskih sustava i solarnih kolektora na krovištu kuće, sakupljanje vode i njezino skladištenje uz opis primjer vlastite izrade calabash sustava kao cisterne za vodu, sustav kućne odvodnje i kompostiranje biorazgradivog otpada. Analizira se industrijska konoplja kao moguć građevinski materijal, pojašnjava se armiranje, izrada kompozita i izolacije od iste. Kod razrade kuća od bala sijena obrazlažu se njihove prednosti i jednostavnost izgradnje. Opisuju se klimatske vrijednosti Istre koje pogoduju izradu autonomnih kuća, te predlaže integriranje sadržaja o gradnji autonomne kuće u nastavu tehničke kulture.
\end{abstract}

Ključne riječi: pasivna kuća; autonomna kuća; sunčeva energija; kuće od konoplje; Istra.

\section{Uvod}

Pojam autonomne kuće prvi put je definiran sedamdesetih godina prošlog stoljeća u sektoru za tehnička istraživanja arhitektonskog fakulteta Sveučilišta u Cambridge-u. Osnovni koncept autonomne kuće predložio je profesor Alexander Pike, kao dio priprema za konferenciju Ujedinih
Naroda o održivom razvoju održanu 1972. godine u Stockholmu. Glavni cilj istraživanja bio je osmisliti sustav opsluživanja za zgrade, a koji smanjuje ovisnost o lokalnim komunalijama (Vale, Vale, 2000).

Brenda i Robert Vale definiraju autonomnu kuću kao kuću koja funkcionira neovisno o bilo kakvim ulazima, osim onih u njenom 
neposrednom okolišu (Vale, Vale, 2000). Takva kuća nije povezana na osnovne mrežne usluge plina, vode, struje ili kanalizacije, već koristi ulaznu energiju sunca, vjetra i kiše i obrađuje vlastiti otpad.

Svaki projekt autonomne kuće podrazumijeva i tehnološke specifikacije potrebne za izgradnju i njeno održavanje. Moderne tehnologije za izgradnju treba razmatrati sa stanovišta onečišćenja okoliša, trošenja neobnovljivih prirodnih resursa, te socijalnih i političkih razloga.

Autonomna kuća da bi bila održiva mora se koristiti alternativnim tehnologijama koje su za nju projektirane. Ona je ovisna o resursima koji se prikupljaju na njezinoj lokaciji, a tehnologija koju ona koristi za iskorištavanje tih resursa treba biti jednostavna, robusna i pod kontrolom stanara.

Prijenos građevinskog materijala do mjesta izgradnje kuće pridonosi onečišćenju okoliša. Cilj kod izgradnje autonomne kuće je da se glavnina građevinskog materijala preuzme iz njenog neposrednog okoliša, tako da bi isti imao najniži ekološki trošak. Jednom kada je autonomna kuća prostorno određena, potrebno je odrediti izgled nje same. Kuća mora biti jednostavnog dizajna kako bi mogla biti jednostavna za izgradnju, a dizajn trajan u vremenu i ne baziran na trenutnim arhitektonskim trendovima (Crawley, Pless, Torcellini, 2009).

Pasivna kuća u stručnom žargonu označava "kuću bez grijanja" (Crawley, Pless, Torcellini, 2009). U kontekstu istarskog podneblja je jedna od odličnih ideja za realizaciju, jer su prosječne temperature u priobalnom području od 4 do $24^{\circ} \mathrm{C}$ („Klima u Istri“, 2017). Pasivne kuće imaju vlastite izvore topline (kućanski uređaji, akumuliranu toplinu konstrukcije, čovjeka i mnoge druge), koriste toplinu/rashladnu energiju zemlje i sunčevu energiju.

Uvjet pasivne kuće je maksimalno toplinsko opterećenje od $10 \mathrm{~W} / \mathrm{m}^{2}$. Godišnje energetske potrebe za zagrijavanje kućanstva ovakve vrste gradnje je manja od $15 \mathrm{kWh} / \mathrm{m}^{2}$. Za sve građevine koeficijent prolaza topline vanjskog omotača građevine ne smije biti iznad dopuštenih vrijednosti od $0,15 \mathrm{~W} / \mathrm{m}^{2} \mathrm{~K}$, a za vrata i prozore smije biti maksimalno do $0,88 \mathrm{~W} / \mathrm{m}^{2} \mathrm{~K}$. Da bi se postiglo čim veće zagrijavanje sunčevom energijom potrebna je velika otvorenost južnog pročelja prozorima, a debljina toplinske izolacije mora iznositi od 25 do 40 centimetara ovisno o materijalu (Miščević, 2005).

Koncept pasivnih kuća iz kojeg su proizišle spomenute norme je nastao pilot projektom 1991. u Darmstadtu, koji je razradio dr. sc. Wolfgang Feist (Passivhaus Institut) i taj se projekt iskazao kao preteča standardu pasivnih kuća koje su se na tržištu pojavile od 1998. Također u projektu CEPHEUS (Cost Efficient Passive Houses as European Standard) dr. Fiest je praćenjem nekoliko stotina kuća dokazao da se pasivne kuće mogu napraviti dostižnim sredstvima (Zbašnik Senegačnik, 2009).

Standard pasivne kuće se ne razlikuje od kuća koje su građene po Pravilniku o toplinskoj zaštiti i učinkovitoj uporabi energije u zgradama i nema dodatnih fizikalno - građevnih zahtjeva, nego izvedba postavlja visoke zahtjeve upotrebe komponenata kao što su (Zbašnik Senegačnik, 2009):

- toplinska zaštita: prolaz topline $U$ svih građevinskih elemenata mora biti manji od $0,15 \mathrm{~W} / \mathrm{m}^{2} \mathrm{~K}$;

- izvanredna zrakonepropusnost, kontrolirana $\mathrm{s}$ tlačnim pokusom po DIN EN 13829 - vrijednost $\mathrm{n}_{50}$ pri 50 Pa tlačne razlike ne smije prijeći 0,6 $1 / \mathrm{h}$;

- ostakljenje $s U_{w}$ ispod $0,8 \mathrm{~W} / \mathrm{m}^{2} \mathrm{~K}$, pri visokom faktoru prolaza cijeloga sunčeva zračenja, tako da su zimi mogući dobitci topline;

- najniže toplinske gubitke pri pripremi $i$ distribuciji sanitarne vode;

- učinkovito iskorištavanje električne energije u gospodarstvu (uređaji iz energetskog razreda A i $A+)$.

Ovo su samo osnovna polazišta koja treba poštivati kada se gradi pasivna kuća. Pri tome treba paziti da se ukomponiraju svi materijali koji pospješuju smanjenu emisiju ugljičnog dioksida i da treba napraviti smisleni projekt.

Također je za pasivnu kuću potrebno predvidjeti mehanički sustav ventilacije $s$ rekuperatorom topline obzirom da je kuća previše nepropusna za minimalnu potrebnu količinu zraka (obično 0,4 ili 0,5 izmjena zraka na sat), dok 
omotač propušta samo 0,1 izmjenu na sat, što je premalo za potrebe za kisikom. Naime bez mehaničkog sustava ventilacije korisnici otvaraju prozore i ventiliraju kuću, ali se na takav način povećavaju ventilacijski gubici topline, a potrebna toplina za grijanje raste iznad granice od 15 $\mathrm{kWh} / \mathrm{m}^{2}$ god.

$\mathrm{U}$ radu se stoga obrađuje koncept pasivne kuće koja je ujedno i autonomna, obzirom da nije nužno priključena na mrežne usluge, na način da se analizira orijentacija kuće, razrađuje koncept $\mathrm{i}$ izvedba samostalnog fotonaponskog sustava, solarnih kolektora, opskrbe vodom, sustava kućne odvodnje i kompostiranja biorazgradivog otpada. Potom se razmatraju građevni materijali, gradnja i predlaže rješenje autonomne kuće u Istri, uz prijedlog primjene sadržaja teme $u$ nastavi za osnovnu školu.

\section{Orijentacija kuće}

Količina dobivene energije ovisi o godišnjem dobu i dnevnom kretanju sunca. Treba voditi računa da Sunce zimi obasjava južnu stranu, čime utječe na veću površinu zagrijanog prostora u odnosu na orijentaciju prema zapadnoj $i$ istočnoj strani. $U$ ljetnom periodu sunce obasjava više zapadnu i istočnu stranu, a najmanje južnu (slika 1).

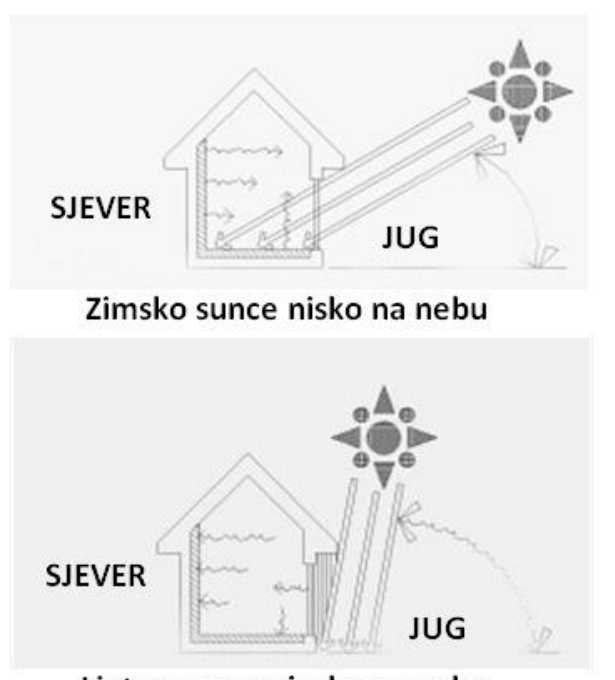

Ljetno sunce visoko na nebu
Slika 1. Ljetno i zimsko obasjavanje kuće (Zelena energija, 2014)

Stoga je u doba velikih vrućina, ljeti, te hladnih i kratkih dana, zimi, za obasjavanje autonomnih kuća koje imaju velika staklena pročelja idealna orijentiranost pročelja na južnu stranu.

Također treba voditi računa o postojanju raslinja u blizini kuće, posebno stabala, radi sljedećeg:

- ušteda energije potrebne za hlađenje zbog obuzdavanja sunčevog zračenja sjenom koja štiti ljude, tlo, nepropusne površine, građevine i druge površine koje asporbiraju sunčevu energiju i potom ju ozrače natrag u okoliš;

- ušteda energije ljeti zbog evapotranspiracije putem površine lišća, što ima učinak hlađenja na okolni zrak;

- ušteda energije smanjivanjem gubitka energije zračenjem iz domova i od ljudi (dokaz su zeleni krugovi ispod stabala kod jutarnjih mrazova);

- ušteda energije zimi zbog smanjenja utjecaja vjetra.

\section{Samostalni fotonaponski sustavi}

$\mathrm{U}$ radu su obrađeni mali fotonaponski sustavi koji se mogu instalirati na krovište kuća ili u neposrednoj blizini na parceli te nisu povezani na sustav opskrbe električne energije koju isporučuje mrežni opskrbljivač (engl. off - grid). Takvi sustavi se nazivaju samostalni fotonaponski sustavi (engl. stand - alone systems), koji se mogu izvoditi s akumulatorima za pohranu energije ili mogu biti u kombinaciji s različitim generatorima.

Putem fotonaponskih modula se sakuplja energija sunca koja se pohranjuje $u$ akumulatoru da bi se mogla trošiti u razdobljima kada nema sunca. Regulatori punjenja su potrebni da se akumulatori ne bi pregrijavali uslijed stanja napunjenosti i time prouzročili velike štete sustavu. Teoretski, kada je akumulator pun, a ima i dalje sunčeve energije koja obasjava sustav $i$ trošila rade, može se koristiti direktna potrošnja proizvedene energije.

Na slici 2 su primjeri ugradnje fotonaponskih modula u Drnišu, lijevo, snage 6,12 kW i u 
Čakovcu, desno, snage 6,72 kW, koji su poradi zakona odnosno ugovora o povlaštenom proizvođaču spojeni na javnu elektroenergetsku mrežu i time nisu u energetskom smislu dio autonomne kuće. Nakon proteka ugovorenog razdoblja fotonaponski sustav se može prebaciti na autonoman način rada uz korištenje backup sustava, odnosno baterija, CHP ili dodatnog izvora struje (npr. iz male vjetroelektrane) za razdoblja bez sunca.
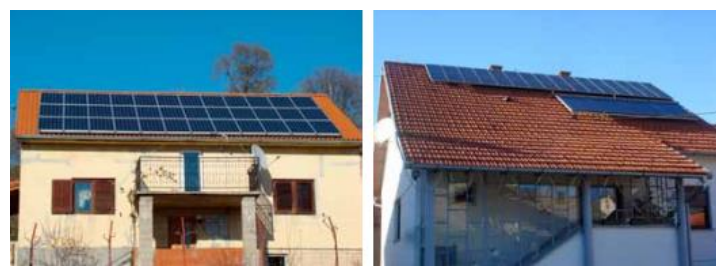

Slika 2. Fotonaponski moduli na krovu, lijevo 6,12 kW i desno

\section{$6,72 \mathrm{~kW}$}

Samostalni fotonaponski moduli su idealno rješenje za pasivne kuće. Najniža cijena postrojenja za jedno kućanstvo bez posebnih dozvola se kreće oko $7000 \mathrm{kn}$ za $1 \mathrm{~kW}$ na $10 \mathrm{~m}^{2}$. Uz prihod energije od 1000 - $1300 \mathrm{kWh} /$ godišnje, to predstavlja investiciju koja se dugoročno isplati.

\section{Solarni kolektori}

Za potrebe zagrijavanja tople vode potrebno je izraditi solarne kolektore koje je moguće kupiti u slobodnoj prodaji, ali za najmanje dvostruko višu cijenu nego kada se oni izrađuju sami. Potrebni materijali za izradu jednog solarnog kolektora su prikazani u Tablici 1.

\begin{tabular}{|l|l|c|}
\hline Materijal & Dimenzije $(\mathrm{mm})$ & Količina \\
\hline Čelični U profil & $2000 \times 100 \times 1,25$ & $4 \mathrm{kom}$ \\
\hline Aluminijski lim & $2000 \times 1000 \times 0,5$ & $2 \mathrm{kom}$ \\
\hline Aluminijski L profil & $20 \times 20$ & $6 \mathrm{~m}$ \\
\hline Kaljeno staklo & $1985 \times 985 \times 4$ & $1 \mathrm{kom}$ \\
\hline Alu folija & Debljine 0,1 & $2 \mathrm{~m} 2$ \\
\hline Bakrene cijevi & $\varnothing 22$ & $2,5 \mathrm{~m}$ \\
\hline Bakrene cijevi & $\varnothing 15$ & $10 \mathrm{~m}$ \\
\hline Bakreni T fitinzi & T22/15/22 & $10 \mathrm{kom}$ \\
\hline Električarska žica & $2,5 \mathrm{~mm} 2$ & $6 \mathrm{~m}$ \\
\hline Pop zakovice & $4 \times 8$ & $70 \mathrm{kom}$ \\
\hline Kamena vuna & Debljina 50 & $2 \mathrm{~m} 2$ \\
\hline Crna mat boja za metal & $200 \mathrm{~g}$ & $1 / 4$ tegle \\
\hline Žica za meko lemljenje & $3 \mathrm{~mm}$ & $1 / 4 \mathrm{role}$ \\
\hline Pasta za lemljenje & & $1 / 4 \mathrm{kutije}$ \\
\hline Silikonnski kit- prozirni & & $1 / 2$ tube \\
\hline $\begin{array}{l}\text { Silikonski kit otporan na visoke } \\
\text { temperature }\end{array}$ & & $1 \mathrm{tuba}$ \\
\hline
\end{tabular}

Tablica 1. Potreban materijal za izradu kolektora. Izvor: autorovo sudjelovanje na radionici u sklopu proljetne škole tehničkih aktivnosti u ožujku 2016

Izrada solarnog kolektora započinje izradom upijača energije (solarnog apsorbera) koristeći materijale iz Tablice 1. Preko njega se svjetlosna energija Sunca pretvara u toplinsku. Isti se sastoji od aluminijskih krilca na kojima se uz pomoć ručne hidraulične preše naprave $U$ - profili za bakrene cijevi koje kasnije čine povezanu nepropusnu rešetku. Nakon toga se uz pomoć bakrene žice krilca na kojima su izbušeni provrti $\varnothing$ $3 \mathrm{~mm}$ (Slika 3) vežu na bakrenu rešetku koju, primjerice u nastavi, može izraditi drugi tim učenika (Slika 4). Radi boljeg učvršćivanja koristi se silikonski kit otporan na visoke temperature $i$ time poboljšava učvršćenje krilca. Nakon toga 
izradi se aluminijski okvir koji se spoji slijepim zakovicama i potom krilca, cijevi i okvir premažu crnom bojom radi bolje apsorpcije topline (Slika $5)$.

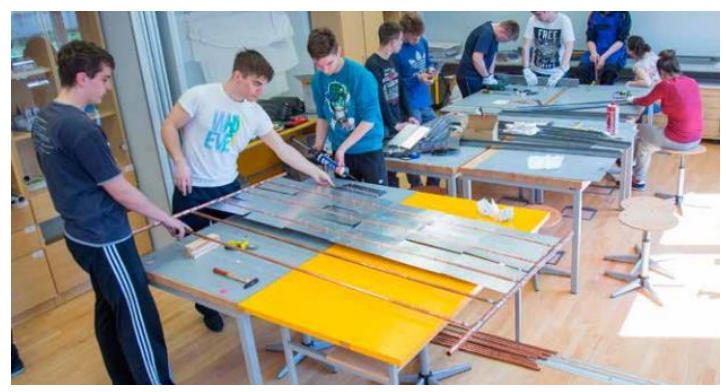

Slika 3. Izrada bakrene rešetke i okvira

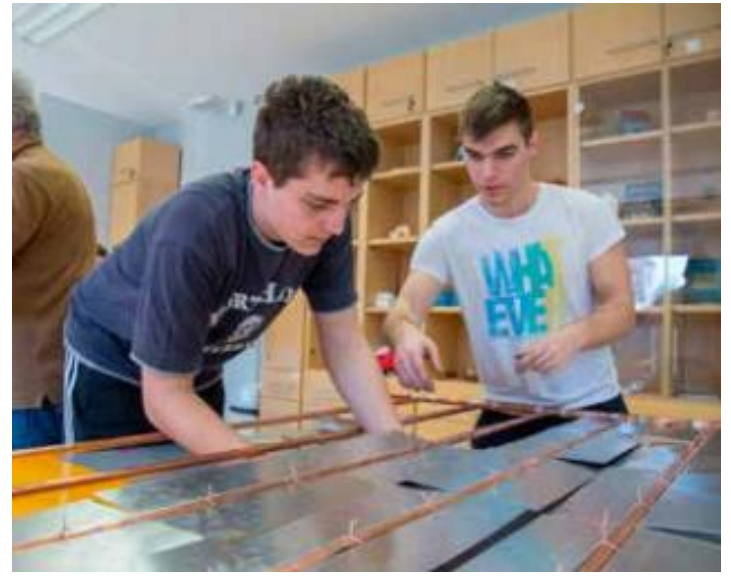

Slika 4. Povezivanje aluminijskih krilca bakrenom žicom
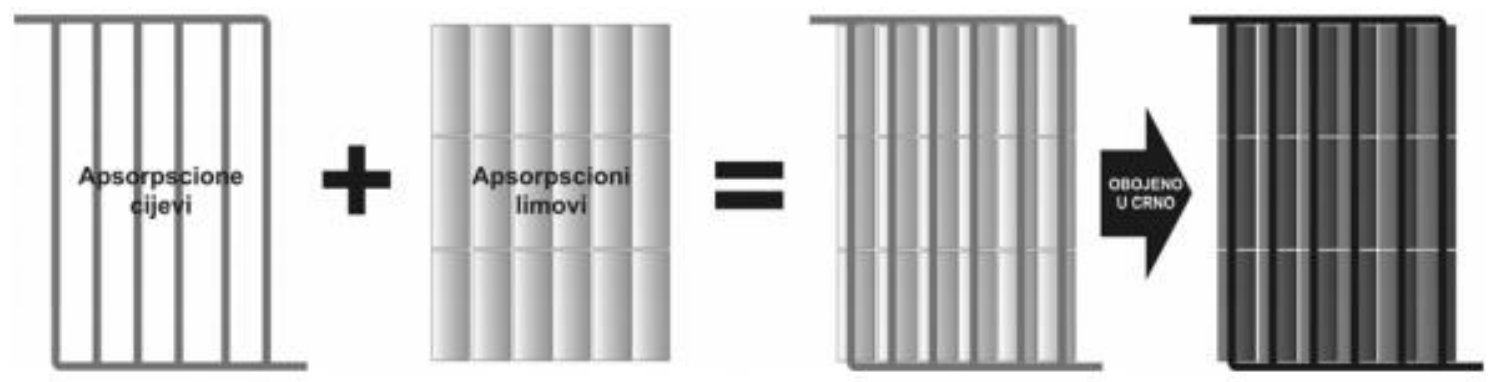

Slika 5. Shema sastavljanja toplinskog kolektora (Centar za ekologiju i energiju Tuzla, 2006)

U okvir se umetne mineralna vuna kao izolacijsko sredstvo i preko nje postavi aluminijska folija na kojoj leži bakrena rešetka s krilcima i sve skupa zatvori staklenom prozirnom pločom (Slika 6).

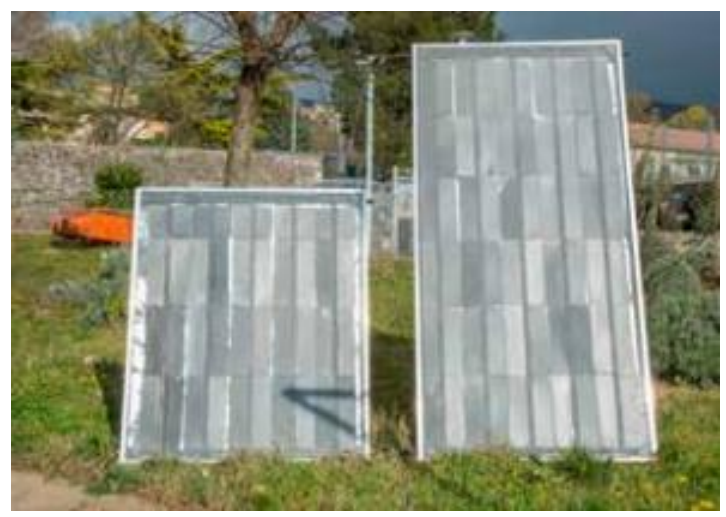

Slika 6. Gotov solarni kolektor

Radi jednostavnosti izrade samog kolektora nije nužno kupovati gotov proizvod nego ga se može samostalno izraditi, što doprinosi uštedi.

Instalacija fotonaponskih panela i kolektora je vrlo slična pa se u daljnjem tekstu pojašnjava principe instaliranja kolektora koji se može primijeniti na oba sustava. Instalaciju je najbolje obaviti na južnu stranu krova, no nije nužno. Ako postoje uvjeti da se postave negdje drugdje na parceli gdje ima više sunca, onda je to poželjno napraviti, a konstrukcijski je vrlo slično.

Na krovište se postavljaju L - profili koji su napravljeni prema dimenzijama kolektora i imaju zaštitni premaz protiv korozije. Kućišta imaju provrte za montiranje na krovne nosače i za pričvršćivanje kolektora. Kućište istovremeno 
odiže kolektor cca $10 \mathrm{~cm}$ od krovišta da kiša može slobodno protjecati niz krov i pridržava kolektor da ga vjetar ne bi otpuhao

Pričvršćivanje konstrukcije treba izvesti tako da se napravi provrt kroz crijep i gredu, postave se ogovarajući vijci kroz distancer, npr. bakrena cijev koja udaljava metalni nosač za $10 \mathrm{~cm}$ od crijepova kako bi voda, zrak i snijeg mogli prolaziti. Pričvrste se vijci $s$ maticama i odgovarajućim podloškama, te potom nanese silikon između crijepa i bakrene cijevi kako bi se onemogućilo prodiranje vode pod crijep (Slika 7).

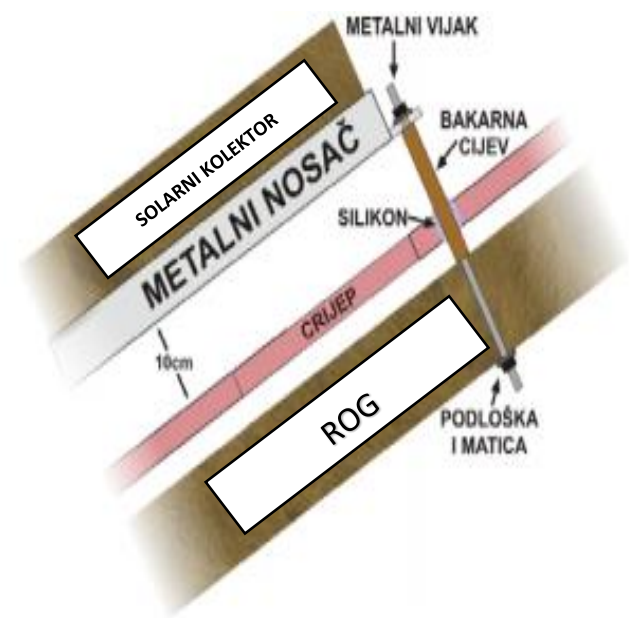

Slika 7. Postavljanje metalne L - konstrukcije i solarnog kolektora (Centar za ekologiju i energiju Tuzla, 2006)

Naposljetku se cijeli sustav poveže $s$ instalacijama koje su provedene po kući, a na vrhu gdje je najviša točka postavlja se na cjevovod ventil za ozračivanje koji ispušta zrak koji se $s$ vremenom skuplja u cjevovodu, što može dovesti do nepravilnog rada sustava i izbijanja kvarova.

Aktivni sustav zatvorene petlje (Slika 8) ima svoje prednosti u krajevima kao što je Istra jer je voda puna kalcijeva karbonata (kamenca), koji bi mogao uslijed dugotrajnog rada $\mathrm{i}$ povišene temperature dovesti do kvarova samog sustava. $\mathrm{Na}$ ovaj način to se sprječava i moguće je u vodu dodati antifriz koji u hladnim vremenskim razdobljima štiti vodu od zamrzavanja.

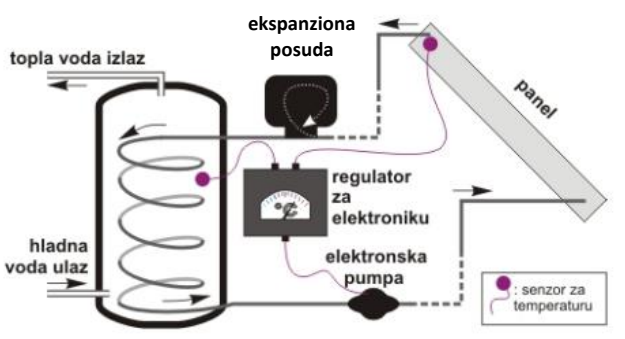

Slika 8. Aktivni sistem zatvorene petlje (Centar za ekologiju i energiju Tuzla, 2006)

Sustav se sastoji od panela koji grije vodu koja prolazi cijevima, i putuje kroz sustav. Povišenjem temperature se povećava i volumen vode pa je potrebno postaviti ekspanzionu posudu da se uravnoteži tlak u cijevima. Cijevi s toplom vodom tada spiralno idu kroz bojler u koji dolazi potrošna voda koju zagrijava kao izmjenjivač topline. Ohlađena voda se elektronskom pumpom šalje ponovo u kolektor i na taj način kruži sustavom.

Da bi cijeli sustav efikasno radio potrebno je postaviti i regulator za elektroniku koji je senzorima povezan $s$ bojlerom za vodu, kolektorom i elektronskom pumpom i uz programsku podršku upravlja sustavom.

\section{Opskrba vodom}

Jedan od glavnih izvora života je voda koja je neophodna za autonomne kuće. Voda se u Istri prikuplja još od davnina u cisternama koje su izgrađene u vrtovima. Druga opcija je kopanje bunara, ali tu postoji ograničenje zbog dubine kopanja i raznovrsnih pumpi koje traže dodatna ulaganja. Također postoji i zakonsko ograničenje, jer ako je dubina bušotine iznad propisane vrijednosti, onda je potrebno plaćanje komunalija i time autonomna kuća više nije autonomna. Autor je pohađao radionicu izrade jedne vrste cisterne zvane "CALABASH" koja je izgrađena od gline i slame. Cisternu zapremnine 5000 I moguće je napraviti za 6 dana (De Gevulde Waterkruik, 2016). Na isti način se može napraviti i cisterna ukopana u zemlju, ali zbog bolje vizualne percepcije prikazuje se inačica na površini zemlje. 
Calabash cisterne su dobile naziv prema svom obliku (Slika 9), a u prijevodu bi značilo: "Tikvasti spremnik za pitku vodu". Dalje u tekstu se zbog jednostavnosti koristi izvorni naziv.

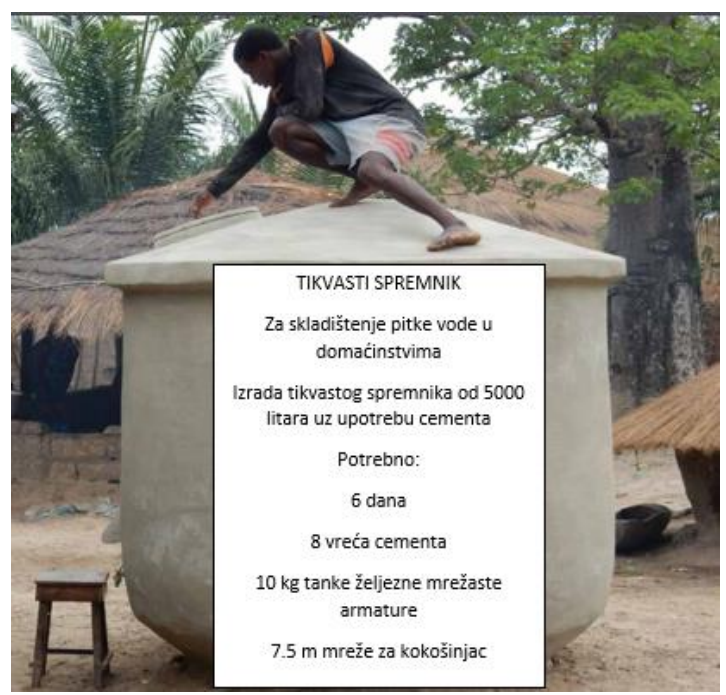

Slika 9. Calabash cisterne za vodu (De Gevulde Waterkruik, 2016)

Oblik nije slučajno odabran. Naime opisani oblik pospješuje čvrstoću same konstrukcije da ne bi nastale pukotine $u$ oplati i time došlo do propuštanja.

Potrebni materijali su sljedeći:

- 240 glinenih blokova za izradu kostura (vanjskih rubova spremnika) $15 \times 15 \times 30 \mathrm{~cm}$, a isti glineni blokovi se kasnije mogu ponovo koristiti za izradu novih spremnika ili za drugu namjenu;

- 8 vreća cementa od $50 \mathrm{~kg}$;

- $10 \mathrm{~kg}$ mekane čelične mreže;

- 7.5 m mreže za kokošinjac;

- $8 \mathrm{~m}$ plastične folije širine $2 \mathrm{~m}$;

- $50 \mathrm{~cm}$ čelične šipke, debljine $\varnothing 6 \mathrm{~mm}$ za rukohvat;

. 20 kolica gline;

. 600 I vode.

Druga mogućnost na autonomnim kućama su plastični kontejneri koji sakupljaju kišnicu ili se mogu puniti cisternama. Spremnici su izrađeni od HDPE plastike za koju se smatra da je najsigurniji kontejner, jer ispušta najmanje kemikalija. Spremnici imaju najčešće metalni okvir i izlaze za crijevo te se time može koristiti za navodnjavanje ili ako se na vanjski dio priključi pumpa za vodu onda se ta voda može koristit i u kućanstvu.

Zapremina je od $1055 \mathrm{I}$, težine do $25 \mathrm{~kg}$ a njihova se cijena kreće oko 1500 kn (slika 10) i moguće in je pronaći u okolnim lancima trgovina.

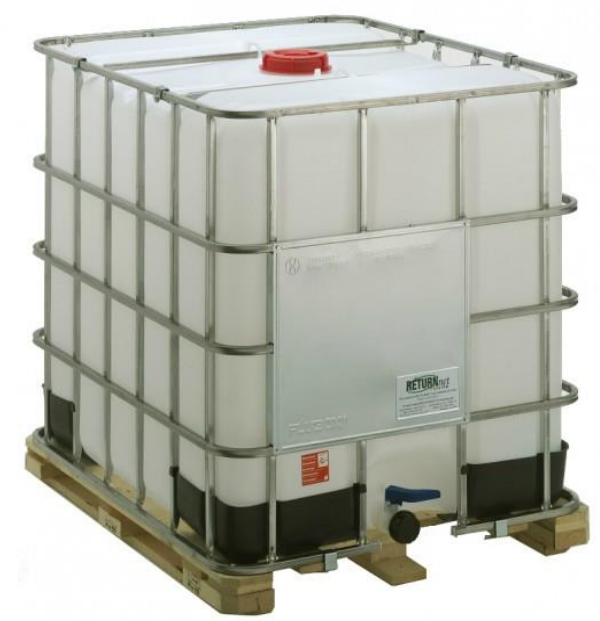

Slika 10. Kontejner za vodu od 1000 I (izvor: katalog Bauhaus)

Iz vlastitog iskustva, jedno domaćinstvo na mjesečnoj bazi trebalo bi potrošiti oko 4000 I vode za tročlanu obitelj. Kontejneri bi se mogli postaviti jedan pored drugoga i povezati tako da iz jednog voda ide $u$ drugi.

Za ratarstvo bi se mogao postaviti dodatni kontejner za vodu koji bi se punio kišnicom i time bi se smanjila potrošnja vode na parceli, a sami spremnici bi se cjevovodom povezali na oluke kuće i tako punili kišnicom.

\section{Sustav kućne odvodnje}

Proračunom za četveročlanu obitelj je utvrđeno da se septička jama u prosjeku napuni sa 560 I po danu. Volumen jame od $35 \mathrm{~m}^{3}$ bio bi napunjen za 62,5 dana. Proizlazi da bi se septička jama konvencionalno praznila jedanput $u$ dva mjeseca za četveročlanu obitelj. Kako bi se smanjio broj naplatnih pražnjenja septičke jame autor predlaže 
da se ugradi mali sustav obrade otpadnih voda čime bi se isto tako postiglo da se tvari nakon odgovarajuće obrade vraćaju u ekosustav na prihvatljiv način.

Naime mali sustav je svaki sustav u kojem se otpadna voda proizvedena na nekom lokalitetu obrađuje i vraća u ekosustav unutar granica tog lokaliteta, a to može bit i jedna kuća. Ukoliko se ne radi o poljoprivrednom imanju, mulj se može dislocirati kako bi ga se vratilo u ekosustav. Mali sustav, slika 11, ima taložnicu i infiltracijsko polje odnosno jarak za raspršivanje otpadne vode u tlo. U slučaju kada tlo ima ograničenja, kao što je visoka razina podzemne vode i nepropusnost sloja, može se koristiti napredni sustav odvodnje kao dio malog sustava gospodarenja otpadnim vodama. Viši stupanj obrade tako omogućava obradu otpadne vode prije ispuštanja na drenažno polje (Runko Luttenberger, 2011).

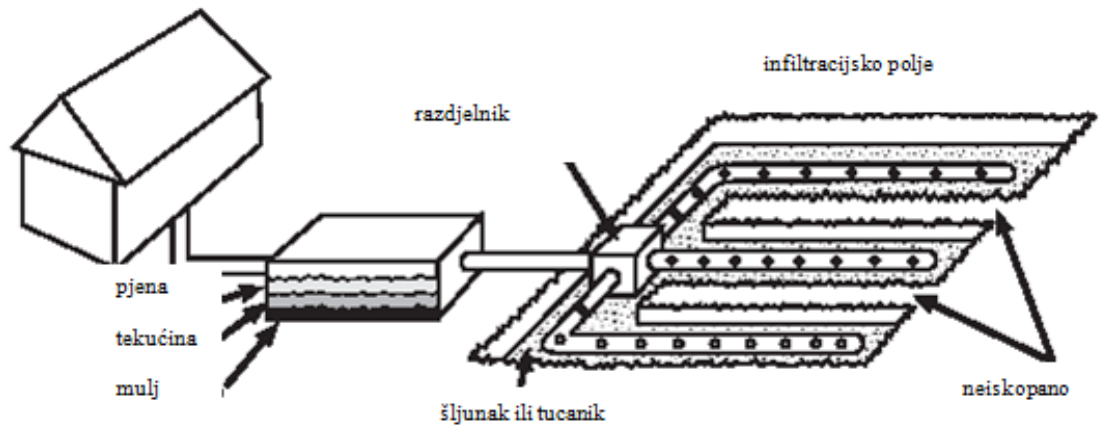

Slika 11. Tipičan septički sustav koji se sastoji od taložnice i infiltracijskog polja (EPA, 2002)

\section{Kompostiranje biorazgradivog otpada}

Kada bi se sav otpad u posudi za smeće razvrstao i odvojeno složio, ustanovilo bi se da organski otpad čini najmanje $30 \%$ ukupnog otpada u kućanstvu. Ostaci voća i povrća, ljuske od jajeta, talog kave, ostaci čaja i biljni otpad iz vrta ubrajaju se u biorazgradivi otpad koji se od davnina kompostiranjem pretvara u korisno dobro. Kompostiranje je prastara metoda pretvaranja organskih ostataka tvari u plodni humus koji se može koristiti u vlastitom vrtu, te predstavlja najprihvatljiviji način zbrinjavanja organskog otpada. Važno je napomenuti da sadnja i prihvanjivanje raslinja, posebice stabala u blizini kuće uvelike doprinosi uštedi energije zbog smanjenja gubitaka energije zračenja, stvaranja sjene, evapotranspiracije, zaklona od vjetra, te također, smanjuje eroziju i oborinsko otjecanje vode.

Kompostiranjem nastaju vrijedne organske tvari koje poboljšavaju strukturu tla, povećavaju mikrobiološku aktivnost tla, pomažu zadržavanju vlage tla, tlo čine prozračnim, obogaćuju tlo hranjivim sastojcima, poglavito dušikom, te povećavaju otpornost biljaka na bolesti i nametnike.

Primjenom kompostiranja se zatvara prirodni ciklus kruženja tvari u prirodi i na taj način se odgovorno $i$ aktivno sudjeluje $u$ rješavanju problema otpada, tj. reciklira se trećina otpadaka. Time se doprinosi povećanju kakvoće okoliša, smanjenju onečišćenja zraka, tla i vode, te smanjenju volumena otpada i rasterećenju odlagališta. Kako tlo predstavlja najveći ponor za ugljični dioksid, humus kojega se tako vraća tlu doprinosi povećanju njegova kapaciteta ponora $i$ time pospješuje reguliranje klime.

Autor se odlučio za kompostiranje $u$ trodjelnom drvenom komposteru. Za ovakav način kompostiranja potrebno je $u$ vrtu predvidjeti površinu od najmanje $4 \mathrm{~m}^{2}$ (Slika 12). 


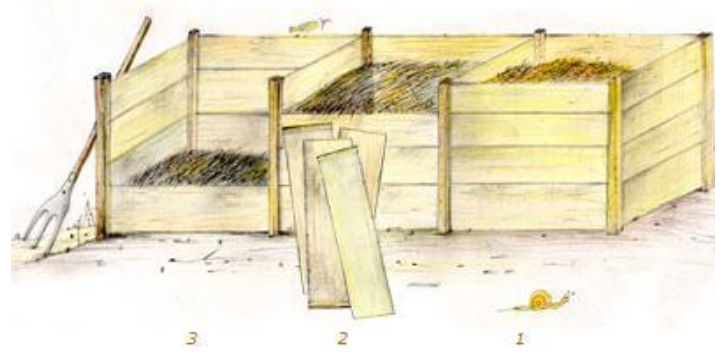

Slika 12. Trodjelni komposter (Lerotić, Lerotić, 2005)

U prvom spremniku se sakupljaju zalihe drvenastog otpada iz vrta: suho granje, grančice, lišće, piljevina i slično. Taj se otpad usitnjava i služi za miješanje $s$ kuhinjskim otpadom čime se regulira vlažnost i poboljšava struktura otpada namijenjenog kompostiranju. Drugi spremnik se puni otpadom iz vrta ili kuhinje, te se pritom miješa sa suhim otpadom iz prvog spremnika. Nakon svakog nanošenja novog kompostnog materijala cijela hrpa se pospe $s$ malo gašenog vapna ili tankim slojem zemlje kako bi se neutralizirao miris. Hrpa se povremeno mora rastresti vilama zbog boljeg kompostiranja otpada. Kada se sakupi dovoljno materijala ili najkasnije nakon 3 mjeseca, kompost iz drugog odjeljka se prebacuje u treći odjeljak i pušta se da dozrijeva. Poželjno je da se prije svakog nanošenja treća hrpa rastrese vilama, a tek onda na nju položi novi materijal iz druge hrpe i to tako da ih se međusobno ne miješa.

Pri kompostiranju mora se paziti na: sastav kompostnog materijala, vlažnost, prozračnost kompostne hrpe i temperaturu komposta. Zrelost komposta može se provjeriti jednostavnim testom sadnje sjemena koji brzo klija, npr. sjeme salate. Zdjelicu s kompostom u kojoj je zasađena salata pušta se na svijetlom mjestu, pazeći pritom na vlažnost. Nakon nekoliko dana provjerava se da li je sjeme ravnomjerno izraslo bez anomalija po lišću. Ako nije tako kompost treba ostaviti još neko vrijeme da dozrije. Uspješnost kompostiranja će biti povećana ako se slijede pravila za uspješno kompostiranje:

- Kompostni materijal nikada ne stavljati u rupu u tlu jer će zbog nedostatka kisika doći do truljenja i neugodnog mirisa;
- Kompost se mora postaviti na propusnu podlogu koja mora biti u izravnom dodiru s tlom kako bi mikroorganizmi iz tla imali nesmetan pristup kompostištu;

- Unutar svakog spremnika treba postaviti na dno oko $20 \mathrm{~cm}$ granja, iverja ili pruća;

- Pokošenu travu treba stavljati tek kada se posuši i to u tankom sloju;

- Organski otpad treba usitniti i svaki odloženi sloj posuti vrtnom zemljom ili gotovim kompostom čime se pospješuje proces razgradnje kompostnog materijala;

- Meso, kosti, i kuhana jela se ne stavljaju na kompostnu hrpu;

- Kompost se mora održavati umjereno vlažnim zbog mikroorganizama kojima je potrebna vlaga, ali ne smije biti previše vlažna jer će isti uginuti uslijed nedostatka kisika;

- Kompostna jama se može pokrivati;

- Kompostnu hrpu treba povremeno preokrenuti i rastresti.

U slučaju da kuća nema okućnicu, odvojeno prikupljeni biootpad može se čuvati u posebnim posudama čiji je sadržaj je sukladno važećoj legislativi obvezan preuzeti pružatelj javne usluge sakupljanja komunalnog otpada koji ga može kompostirati ili digestirati.

\section{Građevni materijali i gradnja}

\subsection{Industrijska konoplja}

Kao građevni materijal upotrebljava se stabljika konoplje, koja se preša u snopove različitih veličina. Iz dugih konopljinih vlakana dobiva se konopljina vuna. Konopljina snažna vlakna osiguravaju stabilnost i dugotrajnost temelja koji su otporni na različite štetnike. Kompozitni materijal je načinjen od mješavine netaljivih makrokomponenata. Sastoji se od matrice (osnovni materijal određenih svojstava) i dodatka (za postizanje potrebnih svojstava). Svojstva kompozita ovise o konstituentima (matrica + dodaci), volumnim udjelima, oblicima, veličinama i o samoj prirodi materijala. Kompoziti s vlaknima imaju povećanu čvrstoću, krutost, otpornost na 
starenje, te poboljšan odnos čvrstoće i težine. Nedostatak im je slaba čvrstoća na povišenoj temperaturi. Kompoziti od konoplje su do dva puta snažniji od drveta $\mathrm{i}$ dobro prenose opterećenje u svim smjerovima, čime je konstrukcija od industrijske konoplje iznimno sigurna.

Kuće od industrijske konoplje su kompozitne kuće. Matricu sačinjavaju vlakna dobivena preradom konoplje, a vapno služi kao vezivo. Postoje raznovrsne mogućnosti izrade, kao npr. blokovi od konoplje i vapna koji se slažu kao cigle ili oplata u koju se postavlja armatura te ulijeva kompozit konoplje i vapna.

Zbog odličnih izolacijskih tehničkih svojstava, danas se od konopljine vune izrađuju izolacijske ploče primjerene za izolaciju podova, vanjskih zidova i krovova. Kao i svi prirodni izolacijski materijali i konoplja omogućava cirkulaciju zraka u prostoru i na taj način sprječava nastanak plijesni, a pritom je i dobar antialergen. Na taj način za čovjeka stvara zdrav životni prostor.

\subsection{Vapno}

Vapno je nesumnjivo najrasprostranjenije $\mathrm{i}$ najčešće rabljeno vezivo u graditeljstvu od začetaka civilizacije do današnjih dana. To nije potrebno posebno isticati jer dokaze da se vapno upotrebljavalo od pamtivijeka susrećemo i na ostacima najstarijih građevina. Relativno jednostavna proizvodnja i dostupnost olakšavala je njegovu primjenu. S vremenom se proizvodnja vapna razvila u raširen i unosan obrt, a u našim se krajevima zbog obilja vapnenca često javljala kao dodatna aktivnost poljoprivrednika za premazivanje stabla biljke protiv insekata. Primjenjuje se za ličenje i dezinfekciju unutrašnjih i vanjskih zidova, te u mnogim drugim djelatnostima.

Proizvodnja vapna štetna je za okoliš jer se tijekom pečenja kalcijeva karbonata na $900^{\circ} \mathrm{C}$ oslobađa ugljikov dioksid. No kada se ujedini s konopljom koja u iznimnim količinama koristi ugljikov dioksid, tada vapno postaje koristan ekološki materijal. Vapno je razgradiv materijal (Slika 13), te ako se građevina uništi, vapno će se iz nje kišama isprati u zemlju.

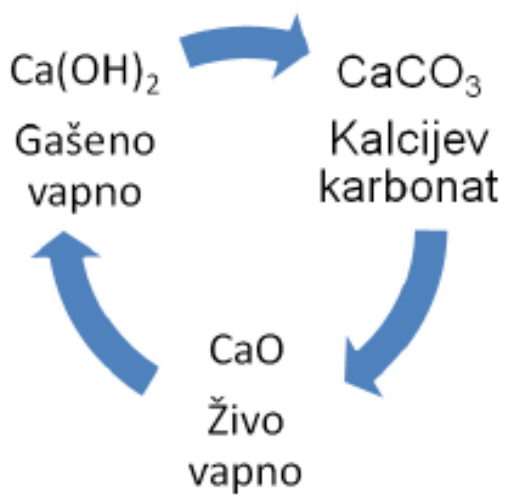

Slika 13. Cirkularni tok vapna

Tako mješavina konopljinih vlakana $\mathrm{i}$ vapna pomiješanog $s$ vodom sačinjava biokompozitni materijal odličnih karakterističnih svojstava. Ovaj kompozit je krut, lagan, dugotrajan i pokazuje odličnu toplinsku izolaciju i paropropusnost.

Vapno je sa svojim kemijskim i fizikalnim svojstvima idealno za kombinaciju s industrijskom konopljom. U svojoj osnovi je lužnato i tako djeluje kao prirodni baktericid te osigurava konopljinom vlaknu sigurnost od plijesni i bakterija.

\subsection{Izgradnja blokova i zidova}

Blokovi od konoplje izrađuju se zato da bi se lakše moglo graditi kuće i u nepovoljnim vremenskim uvjetima radi sušenja kompozita. Blokovi moraju imati armaturu koja može biti od raznovrsnih materijala. Armatura od konopljinih stabljika, jedna je od ekološki najpovoljnijih.

Stabljike konoplje vezujemo konopom od konoplje jednu uz drugu i probijemo kroz sredinu drveni klin. Klin služi da bi se povećala čvrstoća spoja.

Princip je poznat još od davnina, a koristi se i u današnjem armiranju betonskih zidova metalnom žicom. Zidari umjesto armiranog betonskog zida mogu napraviti armirani konopljin zid. Konopljine stabljike mogu se vezati ili u male armature za izradu blokova koji se mogu iskoristiti za konstrukciju pregradnih zidova (Slika 14) ili u lance po cijelom volumenu zida. 


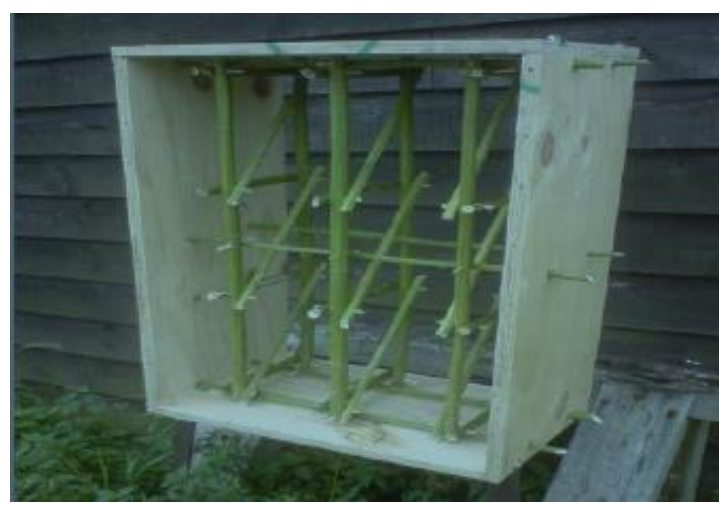

Slika 14. Armirani kalup za konopljin blok (Bell, 2012)

Umjesto konopljine armature može se iskoristiti i armatura od drvenih greda (Slika 15), koja ima odlična nosiva svojstva. Drvene grede su pogodne za velike nosive zidove, lako obradive $i$ dobro se vežu u kompozitu.

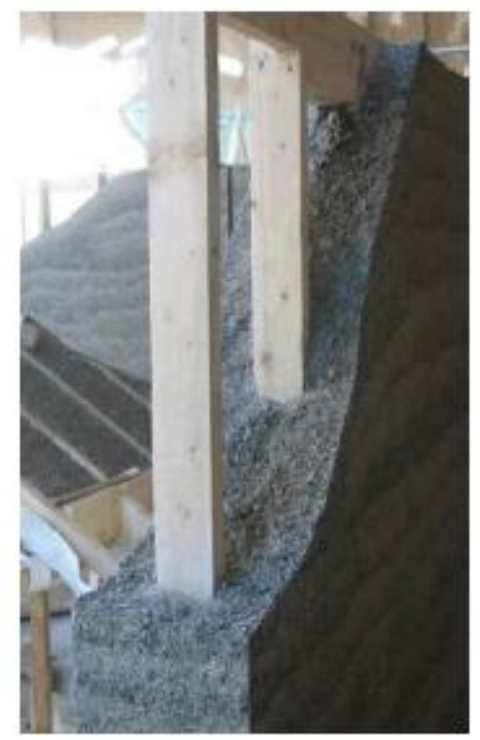

Slika 15. Nosive drvene grede (Bell, 2012)

\subsection{Izolacija}

Izolacijom od konoplje, kao i izolacijom od prirodnih materijala općenito, postiže se izvrsna toplinska izolacija koja istovremeno zadovoljava uvjetima protupožarne i zvučne izolacije i time postaje konkurentna na tržištu izolacija (Vacarius Canna, 2016).

Vlakna od konoplje imaju jedinstvenu sposobnost upijanja vlage i njezinog ponovnog otpuštanja. Zahvaljujući visokoj propusnosti i provođenju vlage, stvara se zdrava mikroklima kuće, čime kuću prirodno štiti od plijesni, bakterija i drugih mikroorganizama odgovornih za izazivanje raznovrsnih alergija i bolesti.

Izolacijske ploče od konoplje na dodir su glatke i ne sadrže iritacijska sredstva te je rukovanje njima vrlo jednostavno i bezopasno. Mogu se koristiti pri izolaciji vanjskih i unutarnjih zidova, stropnoj izolaciji ili izolaciji krova, iako je za izolaciju krova najpogodnije ne staviti ništa jer je zrak najbolji izolator za krovove. Tada krovovi imaju prirodnu ventilaciju i ne stvara se vlaga koja pogoduje mikroorganizmima.

Iz slika napravljenih pomoću termovizijskih kamera može se utvrditi koliko kuće gube toplinu. Modre boje prikazuju manji gubitak topline, a crvena i žuta veći. Prikaz jedne stare betonske kuće (Slika 16.) ukazuje na ogromni gubitak topline kroz zidove.

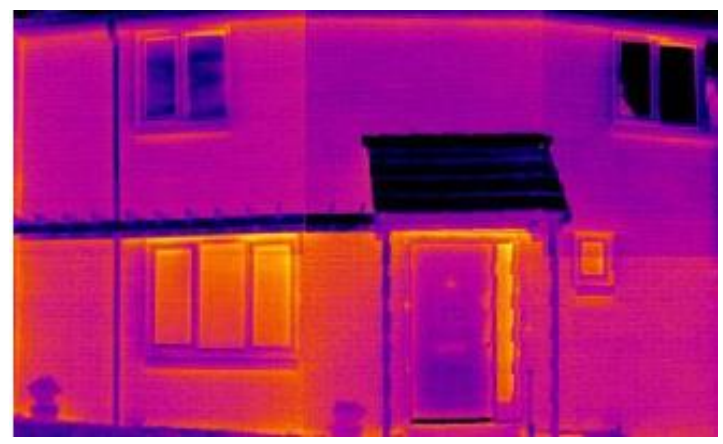

Slika 16. Toplinska postojanost betonske kuće (OldBuilders Company, 2016)

Nasuprot betonskim, kuće od konoplje ne gube toliko topline jer su termopostojane. Prikazana kuća (Slika 17) prikazuje modriju boju zidova i slabije nijanse žute i crvene boje. To znači da je emisija topline manja. 


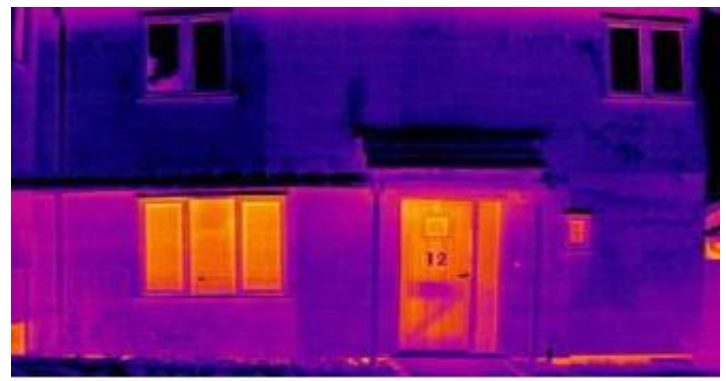

Slika 17. Toplinska postojanost konopljine kuće (Vacarius Canna, 2016)

\subsection{Ekonomska isplativost}

Industrijska konoplja vrlo je prilagodljiva biljka koja dobro uspijeva u našem podneblju. Biljci na našem području potrebno je 120-160 dana od sijanja do košnje pa može imati više uroda godišnje. $U$ doba nezaposlenosti nužno je okrenuti se poslovnim poduhvatima i rješenjima kao što su uzgoj i prerada biljke u svrhu poboljšanja kvalitete i standarda života. Mora se uzeti u obzir da se preradom materijala uštedi i na potrošenoj energiji. Za izradu predmeta od konoplje nije potrebno potrošiti energije koliko i za izradu istog predmeta nekim od postupaka klasičnih konvencionalnih tehnologija. Preradom industrijske konoplje smanjuje se emisija ugljikova dioksida, čime se smanjuju troškovi za filtere $i$ pročišćivače zraka koji su neophodni u mnogim današnjim tvornicama.

$U$ današnje doba imamo traktore za obradu zemlje navođene satelitom i kombajne $s$ laserskom obradom usjeva i sortiranjem pri berbi. Time se ljudski rad zamjenjuje strojem, a pružaju se i mogućnosti za nova radna mjesta. Potiče se i prerada vlakana čime bi se mogle otvoriti tvornice za preradu industrijske konoplje. Otvarale bi se nove trgovine $s$ proizvodima od industrijske konoplje što bi također pridonijelo otvaranju novih radnih mjesta (Pauli, 2012). U građevinarstvu bi se mogao pokrenuti lanac arhitektonskih i projektantskih idejnih rješenja koja bi također donijela nova kvalitetna radna mjesta.

U Republici Hrvatskoj je dopušteno uzgajati konoplju (Cannabis sativa L.) u svrhu proizvodnje hrane za životinje i ljude ukoliko ona ne sadrži u suhoj tvari biljke preko $0.2 \%$ supstance tetrahidrokanabinola. Zahtjev za dobivanje dozvole podnosi pravna ili fizička osoba ministarstvu nadležnom za poljoprivredu. Pravo na dozvolu za uzgoj konoplje ima osoba koja je upisana u Upisnik poljoprivrednih gospodarstava, namjerava uzgajati konoplju na poljoprivrednom zemljištu u vlasništvu ili posjedu na površini većoj od jednog hektara i nije osuđena za kazneno djelo zlouporabe droga najmanje 5 godina od datuma davanja zahtjeva.

Smiju se koristiti sorte koje su priznate u državama Europske unije $i$ nalaze se na zajedničkoj sortnoj listi Europske unije. Sorte konoplje prihvatljive za uzgoj u skladu $s$ pravilnikom su sljedeće: Armanca, Asso, Beniko, Bialobrzeskie, Białobrzeskie, Cannakomp, Carma, Carmagnola, Chamaeleon, Codimono, CS, Deltallosa i druge.

\subsection{Ekološka isplativost}

Konoplja je biljka s iznimno velikim korijenom koji može narasti do $150 \mathrm{~mm}$, te time rahli tlo, što na tvrdim tlima, nepovoljnima za obradu, može poslužiti kao pretkultura za omekšavanje tla. Ujedno je i vrlo otporna na nametnike jer ima svoj obrambeni mehanizam koji je poguban za male organizme. Biljku nije potrebno gnojiti niti tretirati pesticidima i herbicidima.

Povrh toga, vrećice u trgovačkim lancima, koje su napravljene od PVC folije, mogle bi se zamijeniti vrećicama izrađenim od vlakana konoplje, što bi smanjilo uporabu i štete od plastičnih vrećica u okolišu. Naime konopljine vrećice mogu trajati godinama, a u prirodi se razgrade ne ostavljajući nikakve posljedice na okoliš. Time bi se smanjila količina komunalnog otpada i poboljšala kvaliteta okoliša.

\subsection{Kuće od bala slame}

Još jedna ideja za izgradnju autonomnih kuća kojima bi se smanjila količina utrošenog novca je izgradnja kuća od slame (Slika 18). Ideja je poznata još od davnina, a u današnje doba se sve više raspravlja o tome. U Istarskom podneblju 
postoje takve kuće, pa bi ih se i u današnje vrijeme moglo izrađivati.

U procesu gradnje mogu sudjelovati svi pa čak i djeca. Motivacija je puno veća za izgradnju ovakvih kuća od izgradnje kuća od cigle jer su manje cijene i mogućnosti su mnogobrojne. Uštede mogu biti čak i do 30000 kn (Jones, 2006), a tako ušteđena sredstva mogu se iskoristiti za ostala tehnička rješenja kao što su nabava kolektora ili panela, izrada spremnika za vodu ili provođenje instalacija.
Prednost ovakvog tipa gradnje je kombiniranje velike nosivosti i visok stupanj izolacije, što znači da dobijemo građevni materijal koji je ujedno i građevni blok i izolacija u jednom.

Njihova velika mana je otpornost na vremenske uvijete kao što je kiša, međutim takvi problemi se mogu riješiti različitim idejama izrade temelja ili različitim vodonepropusnim premazima kojih danas ima na pretek.

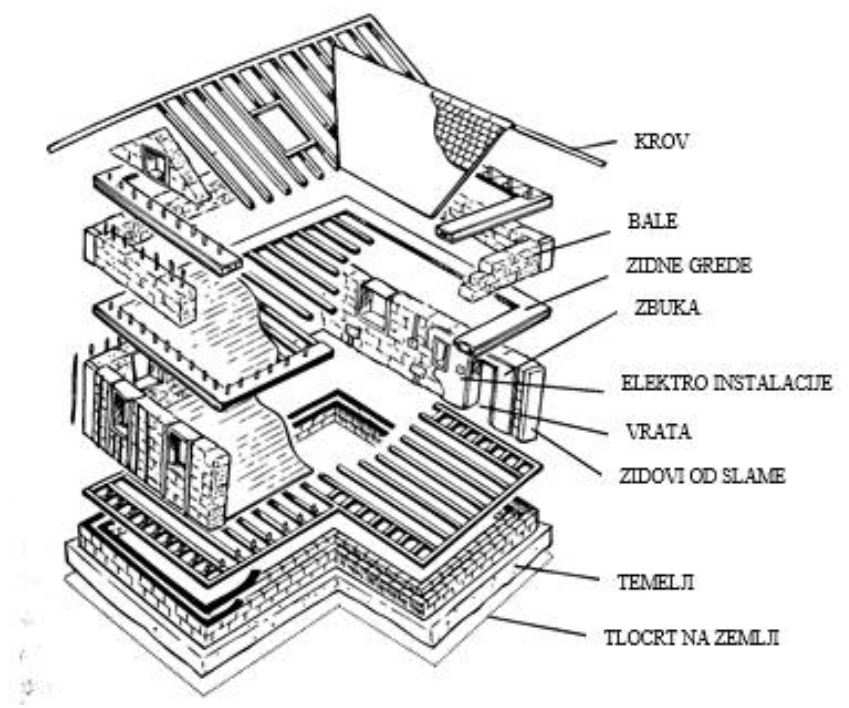

Slika 18. Slamnata dvokatnica od temelja do krova (OldBuilders Company, 2016)

Slama je prirodni materijal koji se može dobiti u neograničenim količinama unutar jednog godišnjeg razdoblja. Ona ne narušava okoliš i dobiva se procesom fotosinteze, a ako nam objekt više nije potreban ista se može kompostirati. Bitno je naglasiti da se ne smije brkati sa sijenom što je proizvod košnje trave i slame koja je očišćena od lišća i klasja.

Samo u Velikoj Britaniji se godišnje proizvodi oko 4 milijuna tona slame, od kojih je moguće napraviti oko 450000 kuća godišnje površine od $150 \mathrm{~m}^{2}$.

Konačno, ne treba zaboraviti da oko $50 \%$ stakleničkih plinova (Jones, 2006) se proizvodi transportom građevnog materijala i njegovom proizvodnjom. Radi dobre izoliranosti kuće, smanjuje se potreba za prekomjernim grijanjem na fosilna goriva $\mathrm{i}$ time se smanjuje emisija ugljičnog dioksida i njezina izgradnja može smanjiti emisije stakleničkih plinova. Koeficijent prolaza topline slamnate izolacije iznosi 0.09 $\mathrm{W} / \mathrm{mK}$ (Jones, 2006), što je manje od propisa za pasivne kuće i time smanjuje potrebu za dodatnim izolacijskim sredstvima, a manje je i za 4-5 puta od izolacijskih svojstava suvremenih materijala.

Nadalje, zidovi od slame imaju visok stupanj zvučne izolacije i time čine idealan životni prostor. $\mathrm{U}$ prilog tome ide $\mathrm{i}$ činjenica da su u SAD izgrađena dva studija za snimanje zvuka od bala slame, baš iz razloga njezinih izolacijskih svojstava.

Cijene bala slame u Istri se kreću od 20 - 5 kuna (ovisno o dostavi) za jednu balu sijena ili 
besplatno ako osoba sama zasije žito, tada ima samo troškove benzina za traktor.

Dimenzije slamnatih blokova ovise od stroja do stroja, a autor se odlučio za stroj koji dimenzionira bale: visine $350 \mathrm{~mm}$, širine $450 \mathrm{~mm}$, duljine od $900 \mathrm{~mm}$ i ukupne težine do $30 \mathrm{~kg}$ ovisno o vlazi. Za izgradnju dvokatnice potrebno je oko 400 (Jones, 2006) bala i cijenom bi iznosile oko 6000 kn, što je ogromna razlika ako uzmemo cigle ili blokove koji bi mogli dostignuti i cijenu od $40000 \mathrm{kn}$. Ispitivanjem opterećenja bala sijena u laboratorijima i praksi su pokazala da se od njih može napraviti manja dvoetažna kuća, što je za tročlanu obitelj sasvim dovoljno. Nije samo cijena materijala pogodna nego je i cijena radnika zanemariva, jer ju može graditi i osoba $s$ minimalnim znanjem uz različite priručnike.

Slama kao alternativa modernim materijalima je prirodna i neškodljiva okolišu. Kako je očišćena od svega pa i peludi stvara zdrav životni prostor za ljude koji su alergični. Pogoduje doprinosu sviježeg zraka koji ujedno zrači kuću i izmjenjuje plinove. Za izolacijske elemente se može kao završni sloj koristiti glina ili prirodne boje.

Još jedan od doprinosa vrijednosti gradnje je i sama gradnja koja je zabavna i jednostavna i na taj način pospješuje zdravlju ljudi koji ju grade, ona aktivira ljude i radno druženje.

\subsection{Umjetni materijali}

Osim prirodnih materijala koji su povoljni u pasivnoj gradnji, za toplinsku izolaciju može se od anorganskih materijala koristiti miniralna vuna $i$ pjenjeno staklo, te od umjetnih organskih materijala ekspandirani i ekstrudirani polistiren, pjenjeni poliuritan i pjenjeni polietilen. Debljina toplinske izolacije ovisi o materijalu i sastavu zida na koji se postavlja.

\section{Moguće rješenje autonomne kuće u Istri}

Projekt razrađen u ovom radu ima za cilj postavljanje autonomne kuće u Istri kao alternative masovnoj gradnji konvencionalnih kuća. Istra obiluje sunčevom energijom i mnogi bi u skoroj budućnosti trebali okrenuti svoj razvoj u smjeru autonomnih kuća.

$\mathrm{Da}$ bi se prikazala iskoristivost solarnih mogućnosti, potrebno je odrediti solarnu ozračenost područja sjevernog Jadrana, točnije $u$ Gradu Poreču. Autor je koristio kalkulator solarnih vrijednosti Photovoltaic Geographical Information System-a (PVGIS) koji daje podatke procjene dobivene električne energije. Prema unesenim podacima i koordinatama Grada Poreča sa sustavom od $10 \mathrm{~kW}$, gubicima od $14 \%$ i kutom postavljanja na krovu od 40 stupnjeva, dobiju se podaci prikazani Tablicom 2 . Iz podataka se zaključuje da je godišnja dobit oko 13300 kWh što je za jednu četveročlanu obitelj dovoljno, uz uvjet pohrane energije (baterije, mikrokogeneracija) obzirom da je proizvodnja energije iz sunca najveća onda kada je potreba za njom najmanja.

Prema podacima DHMZ-a u Istri u gradu Poreču (Tablica 3), godišnje padne toliko oborina koje bi zadovoljavale potrebe kućanstva. U nekim mjesecima bi se voda sakupljala u spremnik za vodu, a u sušnim bi se trošila. Voda bi se reciklirala i ponovo koristila što je i cilj održivog razvoja.

Energija vjetra nije zanemariva, ali treba uzeti u obzir da se za njezinu proizvodnju potrebni konstantni vjetrovi određenih brzina, ali za neke pomoćne sustave može se iskorištavati.

Može se zaključiti da bi korišteni model autonomne kuće prikazanim u radu i njegova daljnja razrada doprinijela razvoju gospodarstva $\mathrm{i}$ očuvanju okoliša i Istri. Slika 19 je autorova vizija autonomnog gospodarstva sa svim opisanim idejama.

Autonomna kuća mora sadržavati solarne panele za proizvodnju električne energije i solarne kolektore za zagrijavanje vode. Takvi sustavi postavili bi se na krovište kuće. Pročelje kuće bilo bi na južnoj strani i sadržavalo bi velike staklene površine za grijanje. Za izgradnju zidova koristili bi se prihvatljivi kompostni materijali kao što su konoplja ili bale slame. Sustav odvodnje i sakupljanja otpadnih voda predviđa visok udio recikliranja, ponovnog korištenja i vraćanja vrijednih resursa u ekosustav. Autor smatra da je potrebno što bolje iskoristit vodu, pa se ista 
reciklira više puta. Zbog toga postavljaju se na parcelu različiti spremnici za vodu. Calabash spremnik služio bi za pitku vodu, a plastični spremnici bi se mogli koristiti za sakupljanje ostalih voda. Fekalije iz domaćinstva taložile bi se u septičkim jamama, a mulj koji nastaje taloženjem fekalija, koristio bi se za poljoprivredu u kombinaciji s materijalima koji se kompostiraju.

\begin{tabular}{|l|r|r|r|r|}
\hline Mjesec & Ed (kWh) & Em (kWh) & Hd (kWh/m $\left.{ }^{2}\right)$ & Hm (kWh/m $\left.\mathbf{~}^{\mathbf{}}\right)$ \\
\hline Siječanj & 17.10 & 531 & 2.25 & 69.6 \\
\hline Veljača & 28.50 & 799 & 3.74 & 105 \\
\hline Ožujak & 39.20 & 1220 & 5.16 & 160 \\
\hline Travanj & 43.90 & 1320 & 5.79 & 174 \\
\hline Svibanj & 48.00 & 1490 & 6.35 & 197 \\
\hline Lipanj & 49.20 & 1470 & 6.50 & 195 \\
\hline Srpanj & 52.30 & 1620 & 6.91 & 214 \\
\hline Kolovoz & 49.70 & 1540 & 6.55 & 203 \\
\hline Rujan & 43.00 & 1290 & 5.66 & 170 \\
\hline Listopad & 31.90 & 989 & 4.19 & 130 \\
\hline Studeni & 18.90 & 568 & 2.48 & $\mathbf{7 4 . 5}$ \\
\hline Prosinac & 16.50 & 510 & 2.16 & 66.8 \\
\hline \hline Godišnji prosjek & $\mathbf{3 6 . 6}$ & $\mathbf{1 1 1 0}$ & $\mathbf{4 . 8 2}$ & $\mathbf{1 4 6}$ \\
\hline Ukupno godišnje & & $\mathbf{1 3 3 0 0}$ & & $\mathbf{1 7 6 0}$ \\
\hline
\end{tabular}

Tablica 2. Podaci o Sunčevom zračenju (Kalkulator solarne ozračenosti, 2017) gdje su Ed - proizvodnja po danima, Em - proizvodnja po mjesecima, Hd - dnevno Sunčevo zračenje na plohu i Hm - mjesečno Sunčevo zračenje na plohu

\section{\begin{tabular}{l|l|l|l|l|l|l|l|l|l|l|l|l|l} 
Postaja & I & II & III & IV & V & VI & VII & VIII & IX & X & XI & XII 2016.(mm)
\end{tabular}

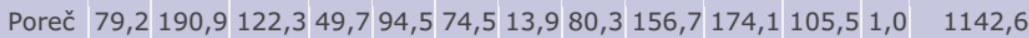

Tablica 3. Ukupne oborine u Istri (Grad Poreč) (Državni hidrometeorološki zavod, 2017)

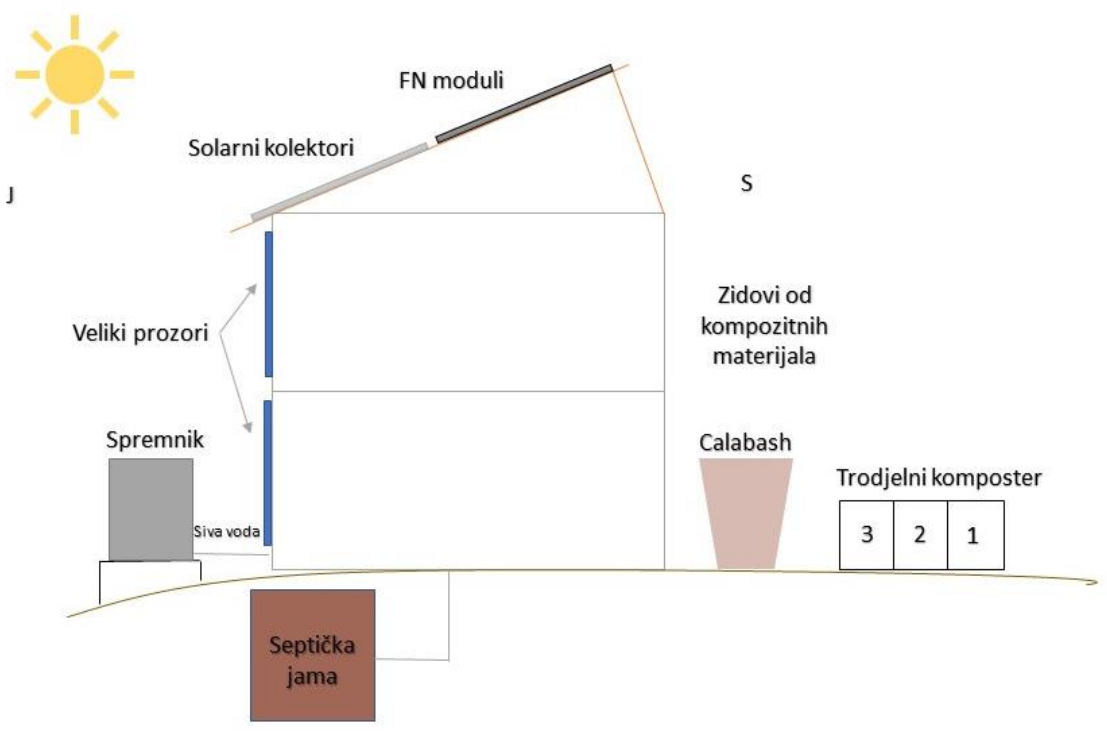

Slika 19. Autorova idejna skica autonomne kuće u Istri 


\section{Zaključak}

U današnje vrijeme kada resursna i energetska učinkovitost postaju imperativ, kuća za stanovanje kao njihov značajan potrošač u kojem sučelje energije, vode i otpada dolazi do punog izražaja, mora biti osmišljena holistički. Rad opisuje rješenja autonomne kuće koja su primjerena istarskom podneblju i gospodarskim mogućnostima. Opisana rješenja pružaju korisnicima kontrolu nad prikupljanjem, gospodarenjem i korištenjem pripadajućeg dijela resursa za zadovoljenje potreba.

Pogodnosti autonomne kuće su smanjeni troškovi izgradnje korištenjem materijala koji se mogu pronaći u prirodi ili na prihvatljivi način uzgojiti i koristiti. $U$ Istri su se autonomne nastambe gradile još od davnina, pa se $\mathrm{i}$ danas treba okrenuti održivom gospodarenju i življenju $\mathrm{u}$ skladu $\mathrm{s}$ prirodom $\mathrm{u}$ zdravom životnom prostoru.

Nužna je promjena zakonodavnog okvira u smislu pojednostavljenja administrativnih procedura i uređenja korištenja svih dijelova industrijske konoplje, vrijedne kulture koja se uzgajala generacijama na našim prostorima. Cijena izgradnje je niža zbog cijene građevinskog materijala, pa se ušteđeni novac može koristiti na druge sustave kao što je izgradnja/nabava solarnog panela ili kolektora kao i na materijale potrebne za izgradnju cisterna za vodu. Isto tako, potrebno je djecu od malih nogu navoditi da razmišljaju u smjeru održivosti, a slamnate kuće predstavljaju dobar izbor za učenike petih razreda kojima to predstavlja zanimljivo gradivo.

Gradnja autonomnih kuća u Istri uvelike bi doprinijela smanjenju potreba za energijom koja se proizvodi iz fosilnih goriva, a time i smanjenju emisija stakleničkih plinova i onečišćenja. Također bi se smanjio pritisak na vodne resurse koji nisu neograničeni, te pospješio povrat hranjivih tvari u tlo. Sami materijali gradnje biljnog podrijetla doprinose razvoju poljoprivrede i zapošljavanju lokalnog stanovništva. Nadalje, ugradnja i održavanje fotonaponskih sustava, kolektora, malih sustava za otpadne vode i sustava recirkulacije vode su radne intenzivne aktivnosti koje tako postaju financijski održive u lokalnoj sredini.

Posebno je gradnja autonomnih kuća važna za Istru s gledišta raspoloživosti resursa zbog turističkog pritiska na gradnju i boravka u Istri višestruko većeg broja ljude tijekom razdoblja $u$ godini u kojem je $i$ inače pojačana potreba za energijom (zbog hlađenja) i vodom, što bi dalje doprinijelo rezlijentnosti istarskog područja. U tom smislu kod svake nove gradnje $\mathrm{i}$ rekonstrukcije organi vlasti i ovlaštenici trebaju iskoristiti svoju regulatornu ulogu u smislu određivanja uvjeta s ciljem uspostave što veće autonomnosti kuća.

\section{Literatura}

Bell M. (2012). The Potential of Hemp: A new approach to the material and its use within the construction industry. Kindle Direct Publishing.

Centar za ekologiju i energiju Tuzla (2006). Priručnik uradi sam solarni kolektor. Preuzeto 17. 07. 2017. sa http://ekologija.ba/wpcontent/uploads/2017/06/Uradi-sam-solarnikolektor.pdf.

Crawley, D., Pless, S., Torcellini, P. (2009). Getting to Net Zero. ASHRAE Journal, 51(9).

De Gevulde Waterkruik (2016). Calabash tank manual. Preuzeto 05. 08. 2017. sa http://degevuldewaterkruik.nl/assets/uploads /pdf/2016/CalabashManual.pdf.

Državni hidrometeorološki zavod (2017). Pristupljeno 25. 07. 2017. na http://www.meteo.hr/.

EPA (2002). Onsite Wastewater Treatment Systems Manual. U. S. Environmental Protection Agency.

Jones, B. (2006). Priručnik za gradnju kuća od bala slame. DataArt+ Studio, Mursko Središće.

Kalkulator solarne ozračenosti (2017). Pristupljeno 25. 06. 2017. na 
http://re.jrc.ec.europa.eu/pvgis/apps4/pvest. php.

Klima u Istri (2017). Preuzeto 25. 06. 2017. sa http://www.istramet.hr/klima-u-istri.

Lerotić, D., Lerotić, T. (2005). Kompostiranje u kućanstvu - mali vodič za početnike. Preuzeto $25 . \quad 08.2017 .2$ sa http://www.lerotic.de/eko/kompost.htm.

Miščević, Lj. (2005). Pasivni energetski standard u graditeljstvu kao perspektiva održivog razvitka - prve pasivne kuće u Hrvatskoj. Zbornik radova Energetske perspektive danas i sutra: Svijet - Europa - Hrvatska, Hrvatsko energetsko društvo, Zagreb.

OldBuilders Company (2016). Hemp-lime building. Preuzeto 25. 06. 2016. sa www.oldbuilders.com.

Pauli, G. (2012). Plava ekonomija: 10 godina, 100 inovacija, 100 milijuna radnih mjesta. Katarina Zrinska.

Runko Luttenberger, L. (2011). Gospodarenje vodom i otpadom - inženjerstvo okoliša u komunalnom gospodarenju vodom i otpadom. Naklada Kvarner, Rijeka.

Vacarius Canna (2016). Prednosti materijala. Preuzeto 24. 07. 2017. sa http://www.konopljaizolacije.hr/hr/prednostimaterijala.

Vale, B., Vale, R. (2000). The New Autonomous House. Thames \& Hudson, New York.

Zbašnik Senegačnik, M. (2009). Pasivna kuća. SUN ARH Zagreb.

Zelena energija (2014). Šta je pasivna solarna kuća i kako funkcionira?. Preuzeto 30. 06. 2017.

http://www.zelenaenergija.org/clanak/sta-jepasivna-solarna-kuca-i-kako-funkcionira/2033.

\section{Model of Autonomous House as Contribution to Sustainable Development of Istria}

\begin{abstract}
The paper analyses the reasons and concept of autonomous houses in Istria as well as the method of energy and material resources use. Elaborated is the principle of producing self-made photovoltaic system and solar collectors on the roof of the house, collecting and storage of water explained on an example of individual calabash system water tank, home wastewater system and composting of biodegradable waste. Analysis is made of industrial hemp as possible building material, explaining the reinforcement, composite making and insulation thereof. In elaborating hay bales house, the advantages and simplicity of construction are pointed out. Climate features of Istria are described which favour the deployment of autonomous houses, and integration of subject matter on autonomous houses into technical culture syllabus is proposed.
\end{abstract}

Keywords: passive house; autonomous house; solar energy; houses of hemp; Istria. 